\title{
HUBUNGAN TINGKAT PENDIDIKAN DAN SIKAP TERHADAP PERILAKU PENGENDALIAN HIPERTENSI PADA LANSIA DI DESA JONO KECAMATAN TAWANGHARJO KABUPATEN GROBOGAN
}

\author{
Oleh; \\ Sutrisno $^{1)}$, Christina Nur Widayati ${ }^{2)}$, Radate $^{3)}$ \\ 1) Staf Pengajar STIKES An Nur Purwodadi, Email; glorious354@gmail.com \\ 2) Staf Pengajar STIKES An Nur Purwodadi, Email; christina.widayati@yahoo.com \\ 3) Mahasiswa STIKES An Nur Purwodadi, Email; annurlppm@gmail.com
}

\begin{abstract}
ABSTRAK
Latar Belakang: Kondisi alam dan masyarakat saat ini sangat kompleks sehingga banyak masalah kesehatan yang muncul, masalah kesehatan pada lansia yang cukup dominan khususnya di negara maju yaitu hipertensi atau tekanan darah tinggi. Perilaku dalam mengendalikan hipertensi dapat dikendalikan dan dapat diatasi jika lansia tahu dan bersikap terhadap apa yang harus dilakukan untuk mengendalikannya. Penelitian ini bertujuan untuk mengetahui hubungan tingkat pendidikan dan sikap terhadap perilaku pengendalian hipertensi pada lansia di Desa Jono Kecamatan Tawangharjo Kabupaten Grobogan.

Metode: Desain penelitian ini adalah Deskriptif Corelation dengan pendekatan Cross Sectional. Teknik sampling yang digunakan adalah purposive sampling dan didapatkan 136 responden yang sesuai dengan kriteria. Teknik pengumpulan data menggunakan kuesioner dan telah dilakukan uji validitas dan reliabilitas. Analisis datanya dengan bantuan computerized menggunakan uji Somersd dengan taraf signifikansi $95 \%$.

Hasil: Berdasarkan hasil analisa data (1) Responden yang memiliki pendidikan menengah sebanyak 79 responden $(58,1 \%)$, (2) responden yang memiliki sikap cukup sebanyak 69 responden $(50,7 \%)$, (3) responden yang memiliki perilaku cukup sebanyak 66 responden $(48,5 \%)$, (4) Ada hubungan tingkat pendidikan dengan perilaku pengendalian hipertensi di Desa Jono Kecamatan Tawangharjo Kabupaten Grobogan menggunakan uji Somers'd nilai r $(0,633)$ dengan p-value $(0,00)<\operatorname{sig}(0,05)$, (5) Ada hubungan sikap dengan perilaku pengendalian hipertensi di Desa Jono Kecamatan Tawangharjo Kabupaten Grobogan menggunakan uji Somers' $d$ nilai r $(0,742)$ dengan p-value $(0,00)<\operatorname{sig}(0,05)$.

Kesimpulan: Berdasarkan hasil uji somers'd disimpulkan bahwa ada hubungan tingkat pendidikan dan sikap terhadap perilaku pengendalian hipertensi pada lansia di Desa Jono Kecamatan Tawangharjo Kabupaten Grobogan.
\end{abstract}

Kata Kunci : Tingkat Pendidikan, Sikap, dan Perilaku 


\section{PENDAHULUAN}

Menurut World Health Organization (WHO) (2011) dalam World Health Day (2013), tekanan darah tinggi merupakan salah satu penyebab kematian lebih awal didunia, sebesar 9,4 juta orang secara global meninggal dan masalah hipertensi ini terus meningkat. Lebih dari 1 milyar orang hidup dengan tekanan darah tinggi. Pada tahun 2008, prevalensi tekanan darah tinggi pada usia lebih dari 25 tahun keatas sebesar $40 \%$.

Prevalensi peningkatan tekanan darah tinggi di Wilayah Afrika sebesar 46 $\%$ dengan penderita hipertensi laki-laki sebesar 46,7 \% dan perempuan sebesar 44,6\% dan terendah di Wilayah Amerika sebesar $35 \%$ dengan penderita hipertensi pada laki-laki sebesar $39 \%$ dan perempuan sebesar 31,5\%. Data diperoleh di Wilayah Asia Tenggara, $36 \%$ orang dewasa menderita hipertensi dengan penderita hipertensi pada laki-laki sebesar $37,3 \%$ dan perempuan sebesar $34,9 \%$

Berdasarkan Profil Kesehatan Jawa Tengah (2011), Kasus tertinggi penyakit tidak menular tahun 2011 pada kelompok penyakit jantung dan pembuluh darah adalah penyakit Hipertensi Esensial, yaitu sebanyak 634.860 kasus $(72,13 \%)$. Prevalensi kasus hipertensi essensial di Provinsi Jawa Tengah tahun 2011 sebesar $1,96 \%$ menurun bila dibandingkan dengan tahun 2010 sebesar 2,00\%. Terdapat tiga kota dengan prevalensi sangat tinggi di atas $10 \%$ yaitu Kota Magelang $(22,41 \%)$, Kota Salatiga $(10,18 \%)$ dan Kota Tegal (10,36\%). Penyakit Hipertensi Essensial pada tahun 2009 dan 2010 menunjukkan adanya penurunan kasus yang cukup tinggi, namun pada tahun 2011 terlihat mulai ada kenaikan jumlah kasus.

Berdasarkan data Dinas Kesehatan Kabupaten Grobogan (2013), bahwa hipertensi menduduki peringkat pertama dengan jumlah penderita terbanyak diantara penyakit jantung dan pembuluh darah yang lain. Pada tahun 2012 jumlah penderita hipertensi sebesar 4.297, pada kelompok umur 5-14 tahun pada laki-laki sebesar 10 penderita dan pada perempuan sebesar 3 penderita, sedangkan pada kelompok umur 15-44 tahun pada laki-laki sebesar 32 penderita dan pada perempuan 424 penderita, sedangkan pada kelompok umur 45-64 tahun pada laki-laki sebesar 137 penderita dan pada perempuan sebesar 1.805 penderita, sedangkan pada kelompok umur lebih dari 65 tahun pada laki-laki sebesar 879 penderita dan pada perempuan sebesar 1.171, pada tahun 2013 jumlah penderita hipertensi sebesar 5.192 penderita, pada kelompok umur 5-14 tahun pada laki-laki sebesar 40 penderita, sedangkan pada kelompok umur 15-44 tahun pada laki-laki sebesar 19 penderita dan pada perempuan 644 penderita, sedangkan pada kelompok umur 45-64 
tahun pada laki-laki sebesar 136 penderita dan pada perempuan sebesar 2.124 penderita, sedangkan pada kelompok umur lebih dari 65 tahun pada laki-laki sebesar 1.035 penderita dan pada perempuan sebesar 1.181.

Berdasarkan data Puskesmas Tawangharjo (2013), menunjukkan bahwa penderita hipertensi setiap tahun mengalami kenaikan yang cukup signifikan. Pada tahun 2011 jumlah penderita hipertensi yaitu sebesar 1.226 penderita, pada kelompok umur 15-44 tahun pada laki-laki sebesar 175 penderita dan pada perempuan 134 penderita, sedangkan pada kelompok umur 45-64 tahun pada laki-laki sebesar 308 penderita dan pada perempuan sebesar 265 penderita, sedangkan pada kelompok umur lebih dari 65 tahun pada laki-laki sebesar 233 penderita dan pada perempuan sebesar 230.

Pada tahun 2012 jumlah penderita hipertensi yaitu sebesar 1.140 penderita, pada kelompok umur 15-44 tahun pada laki-laki sebesar 91 penderita dan pada perempuan 87 penderita, sedangkan pada kelompok umur 45-64 tahun pada laki-laki sebesar 92 penderita dan pada perempuan sebesar 83 penderita, sedangkan pada kelompok umur lebih dari 65 tahun pada laki-laki sebesar 107 penderita dan pada perempuan sebesar 86, Pada tahun 2013 jumlah penderita hipertensi yaitu sebesar
1.193 penderita, pada kelompok umur 1544 tahun pada laki-laki sebesar 64 penderita dan pada perempuan 57 penderita, sedangkan pada kelompok umur 45-64 tahun pada laki-laki sebesar 54 penderita dan pada perempuan sebesar 53 penderita, sedangkan pada kelompok umur lebih dari 65 tahun pada laki-laki sebesar 64 penderita dan pada perempuan sebesar 63.

Jumlah penderita hipertensi di wilayah kerja Puskesmas Tawangharjo yang tertinggi adalah di desa Jono, dengan jumlah penderita pada tahun 2011 sebesar 250 penderita, pada tahun 2012 sebesar 217 penderita, pada tahun 2013 sebesar 206 penderita. kemudian disusul desa Plosorejo, dengan jumlah penderita hipertensi pada tahun 2011 sebesar 194 penderita, pada tahun 2012 sebesar 161 penderita, pada tahun 2013 sebesar 166 penderita. Kemudian disusul desa Tarub, dengan jumlah penderita hipertensi pada tahun 2011 sebesar 149 penderita, pada tahun 2012 sebesar 173 penderita, pada tahun 2013 sebesar 192 penderita.

Faktor-faktor yang menyebabkan hipertensi terbagi menjadi dua bagian yaitu faktor yang dapat dikontrol dan yang tidak dapat dikontrol. Faktor yang dapat dikontrol antara lain merokok, kelebihan berat badan, stress konsumsi garam, alkohol, dan lemak, dan aktivitas fisik (olahraga). Sedangkan faktor yang tidak 
dapat dikontrol antara lain usia, jenis kelamin, ras/etnik, keturunan/genetic (Anggraini dalam Mahardani, 2010).

Menurut Rahajeng \& Sulistyowati (2009), menunjukkan bahwa berdasarkan perilaku merokok, proporsi responden yang dulu pernah merokok setiap hari pada kelompok hipertensi ditemukan lebih tinggi $(4,9 \%)$ daripada kelompok kontrol $(2,6 \%)$, dan risiko perilaku pernah merokok ini secara bermakna ditemukan sebesar 1,11 kali dibandingkan yang tidak pernah merokok.

Tujuan penelitian ini adalah untuk mengetahui hubungan tingkat pendidikan dan sikap terhadap perilaku pengendalian hipertensi pada lansia di Desa Jono Kecamatan Tawangharjo Kabupaten Grobogan.

\section{METODOLOGI}

Desain penelitian ini adalah Deskriptif Correlation dengan rancangan penelitian Cross Sectional merupakan rancangan penelitian dengan melakukan pengukuran atau pengamatan pada saat bersamaan (sekali waktu) antara faktor risiko/paparan dengan penyakit (Hidayat, 2009).

Populasi dalam penelitian ini adalah semua lansia di Desa Jono Kecamatan Tawangharjo Kabupaten Grobogan yang menderita hipertensi adalah 206 responden. Teknik sampling yang digunakan dengan menggunakan metode Purposive Sampling (Saryono, 2009). Analisa yang digunakan adalah uji Somers'd untuk dua variabel dengan skala data ordinal yang tidak sederajat, sehingga rumus umum untuk uji Somers'd.

\section{HASIL DAN PEMBAHASAN}

\section{A. Analisis Univariat}

Tabel 1; Distribusi Berdasarkan

Tingkat Pendidikan

\begin{tabular}{lcc}
\hline Tingkat Pendidikan & $\mathbf{f}$ & $\mathbf{( \% )}$ \\
\hline Rendah & 34 & 25 \\
Menengah & 79 & 58,1 \\
Tinggi & 23 & 16,9 \\
\hline \multicolumn{1}{c}{ Total } & $\mathbf{1 3 6}$ & $\mathbf{1 0 0}$ \\
\hline
\end{tabular}

Tabel 2; Distribusi Berdasarkan Sikap Pengendalian Hipertensi

\begin{tabular}{ccc}
\hline Sikap & $\mathbf{f}$ & $\mathbf{( \% )}$ \\
\hline Kurang & 18 & 13,2 \\
Cukup & 69 & 50,7 \\
Baik & 49 & 36,1 \\
\hline Total & $\mathbf{1 3 6}$ & $\mathbf{1 0 0}$ \\
\hline
\end{tabular}

Tabel 3; Distribusi Berdasarkan

Perilaku Pengendalian Hipertensi

\begin{tabular}{ccc}
\hline Perilaku & f & $(\mathbf{\% )}$ \\
\hline Kurang & 19 & 14 \\
Cukup & 66 & 48,5 \\
Baik & 51 & 37,5 \\
\hline Total & $\mathbf{1 3 6}$ & $\mathbf{1 0 0}$ \\
\hline
\end{tabular}




\section{B. Analisis Bivariat.}

Tabel 5.8 Hubungan Tingkat Pendidikan Terhadap Perilaku Pengendalian Hipertensi Pada Lansia di Desa Jono Kecamatan Tawangharjo Kabupaten Grobogan

\begin{tabular}{|c|c|c|c|c|c|c|}
\hline \multirow{2}{*}{ Tingkat Pendidikan } & \multicolumn{3}{|c|}{ Perilaku Pengendalian Hipertensi } & \multirow{2}{*}{ Total } & \multirow{2}{*}{$\mathrm{R}$} & \multirow{2}{*}{$\begin{array}{l}\text { Sig. (2 } \\
\text { tailed) }\end{array}$} \\
\hline & Kurang & Cukup & Baik & & & \\
\hline \multirow{2}{*}{ Rendah } & 15 & 19 & 0 & 34 & \multirow{8}{*}{0,633} & \multirow{8}{*}{0,000} \\
\hline & $78,9 \%$ & $28,8 \%$ & $0 \%$ & $25 \%$ & & \\
\hline \multirow{2}{*}{ Menengah } & 4 & 47 & 28 & 79 & & \\
\hline & $21,1 \%$ & $71,2 \%$ & $54,9 \%$ & $58,1 \%$ & & \\
\hline \multirow{2}{*}{ Tinggi } & 0 & 0 & 23 & 23 & & \\
\hline & $0 \%$ & $0 \%$ & $45,1 \%$ & $16,9 \%$ & & \\
\hline \multirow{2}{*}{ Total } & 19 & 66 & 51 & 136 & & \\
\hline & $100 \%$ & $100 \%$ & $100 \%$ & $100 \%$ & & \\
\hline
\end{tabular}

Tabel 5.9 Hubungan Sikap Terhadap Perilaku Pengendalian Hipertensi Pada Lansia di Desa Jono Kecamatan Tawangharjo Kabupaten Grobogan

\begin{tabular}{crrrrrr}
\hline \multirow{2}{*}{ Sikap } & \multicolumn{2}{c}{ Perilaku Pengendalian Hipertensi } & Total & R & $\begin{array}{r}\text { Sig. (2 } \\
\text { tailed) }\end{array}$ \\
\cline { 2 - 4 } & Kurang & Cukup & Baik & & 18 & \\
\hline Kurang & 14 & 4 & 0 & $0 \%$ & $13,2 \%$ & \\
Cukup & $73,7 \%$ & $6,1 \%$ & 10 & 69 & \\
& 5 & 54 & $19,6 \%$ & $50,7 \%$ & 0,742 & 0,000 \\
Baik & $26,3 \%$ & $81,8 \%$ & 41 & 49 & \\
& 0 & 8 & $80,4 \%$ & $36 \%$ & \\
Total & $0 \%$ & $12,1 \%$ & 51 & 136 & \\
& 19 & 66 & $100 \%$ & $100 \%$ & \\
\hline
\end{tabular}

\section{PEMBAHASAN}

1. Hubungan Tingkat Pendidikan dengan Perilaku Pengendalian Hipertensi

Berdasarkan dapat diketahui
bahwa responden yang memiliki
tingkat pendidikan rendah dengan perilaku pengendalian hipertensi kurang sebesar 15 responden $(78,9 \%)$ dan responden yang memiliki tingkat pendidikan menengah dengan perilaku pengendalian hipertensi kurang sebesar 
4 responden $(21,1 \%)$. Responden yang memiliki tingkat pendidikan rendah dengan perilaku pengendalian hipertensi yang cukup sebesar 19 responden $(28,8 \%)$ dan responden yang memiliki tingkat pendidikan menengah dengan perilaku pengendalian hipertensi cukup sebesar 47 responden $(71,2 \%)$.

Responden yang memiliki tingkat pendidikan menengah dengan perilaku pengendalian hipertensi baik sebesar 28 responden $(54,9 \%)$, responden yang memiliki tingkat pendidikan tinggi dengan perilaku pengendalian hipertensi baik sebesar 23 responden $(16,9 \%)$.

Berdasarkan hasil penelitian dapat dilihat uji korelasi menggunakan uji Somers'd dengan bantuan komputerisasi.didapatkan hasil uji korelasi tingkat pendidikan dengan perilaku pengendalian hipertensi diketahui nilai $r$ sebesar 0,633 dengan p-value $(0.00)<\operatorname{sig}(0,05)$.

Dari hasil tersebut dapat ditarik kesimpulan bahwa terdapat hubungan tingkat pendidikan dengan perilaku pengendalian hipertensi di Desa Jono Kecamatan Tawangharjo Kabupaten Grobogan. Nilai korelasi tingkat pendidikan dengan perilaku pengendalian hipertensi di Desa Jono Kecamatan Tawangharjo Kabupaten
Grobogan dapat dikatakan kuat, artinya tingkat pendidikan memiliki pengaruh yang kuat terhadap perilaku pengendalian hipertensi di Desa Jono Kecamatan Tawangharjo Kabupaten Grobogan.

Hal ini sesuai dengan teori yang dikemukakan oleh John Dewey dalam Mahyuliansyah (2010), bahwa melalui pendidikan seseorang akan mempunyai kecakapan, mental dan emosional yang membantu seseorang untuk dapat berkembang mencapai tingkat kedewasaan. Semakin tinggi pengetahuannya maka akan semakin bertambah pula kecakapannya, baik secara intelektual maupun emosional serta semakin berkembang pula pola pikir yang dimilikinya.

Menurut Anita (2008) informasi yang cukup dan diterima oleh seseorang dapat menyebabkan seseorang mempunyai pengetahuan yang tinggi sehingga dapat mengaplikasikan pengetahuannya tersebut sesuai peran sertanya di masyarakat. Seseorang yang mempunyai pola pikir yang baik akan mudah beradaptasi pada situasi dan kondisi yang ada di lingkungannya untuk melaksanakan apa yang menjadi tanggung jawabnya, sehingga masyarakat akan cepat tanggap 
terhadap perubahan yang akan dilakukannya.

Hal ini juga didukung dengan teori yang mengatakan bahwa kognitif berperan penting dalam membentuk perilaku atau tindakan seseorang (Maulana, 2008). Pendidikan diperoleh dari pendidikan formal yang ditempuh responden selama mengikuti pendidikan di pendidikan formal. Dengan pendidikan yang dimiliki responden maka akan terbentuk pengetahuan responden yang membentuk perilaku responden tersebut.

Salah satu cara memperoleh pengetahuan menurut Maulana (2008), adalah dengan pengalaman pribadi. Pengalaman ini merupakan sumber pengetahuan atau pengalaman itu merupakan suatu cara untuk memperoleh kebenaran pengetahuan. Pengalaman pribadi yang merupakan cara untuk pengetahuan, selanjutnya pengalaman dapat melihat orang lain yang terkena hipertensi.

Dari kejadian tersebut, responden mempelajari penyebab dan hal-hal apa saja yang patut responden lakukan untuk dapat mengendalikan hipertensi terhadap diri responden. Apabila pengetahuan yang dimiliki individu tersebut juga diikuti dengan urutan perubahan perilaku sesuai dengan ada diteori menurut Rogers dalam Notoatmodjo (2007), maka individu tersebut dapat melakukan pengendalian hipertensi dengan tepat.

Semakin tinggi pendidikan seseorang maka pengetahuan seseorang tentang hipertensi serta bahaya-bahaya yang timbul maka semakin tinggi pula partisipasi seseorang terhadap pengendalian hipertensi. Akan tetapi tingkat pendidikan saja tidak cukup untuk dapat melakukan pengendalian hipertensi sepenuhnya, tanpa diiringi sikap dengan kesadaran akan pentingnya pengendalian hipertensi yang akan diiringi oleh tindakan yang nyatadalam kehidupan sehari-hari. karena apabila seorang individu hanya sekedar tahu saja tetapi tidak mempunyai keinginan untuk merubah pola kebiasaannya sehari-hari semuanya akan sia-sia dan tidak ada gunanya.

Tingkat pendidikan lansia juga salah satu upaya pengendalian hipertensi seperti mengetahui gejala dari hipertensi, mengetahui faktorfaktor yang bisa mengendalikan pada lansia. Apabila penderita hipertensi tidak mengendalikan tekanan darahnya, sehingga terjadi hipertensi maka akan berdampak pada terjadinya stroke. Stroke dapat terjadi perdarahan 
di otak, atau akibat embolus yang terlepas dari pembuluh darah non otak yang terpajan tekanan tinggi. Stroke dapat terjadi pada hipertensi kronik apabila arteri-arteri yang memperdarahi otak mengalami hipertrofi kronik dan penebalan, sehingga aliran darah ke daerah-daerah yang dipendarahnya berkurang. Arteriarteri otak yang mengalami arteriosklerosis dapat melemah dan kehilangan elastisitas sehingga meningkatkan kemungkinan terbentuknya aneurisma (Brunner \& Suddart, 2002).

Hasil penelitian ini sesuai dengan hasil penelitian yang dilakukan oleh Phitaloka (2010), dengan judul faktorfaktor yang berhubungan dengan pegendalian hipertensi pada lansia di Posyandu Lansia Wilayah Kerja Mojosongo Boyolali 2010, dimana dalam penelitian ini menemukan adanya hubungan antara pendidikan dengan pengendalian hipertensi pada lansia di Posyandu Lansia Wilayah Kerja Mojosongo Boyolali 2010.

\section{Hubungan Sikap dengan Perilaku Pengendalian Hipertensi}

Berdasarkan hasil penelitian dapat diketahui bahwa responden yang memiliki sikap kurang dengan perilaku pengendalian hipertensi kurang sebesar
14 responden $(73,7 \%)$ dan responden yang memiliki sikap kurang dengan perilaku pengendalian hipertensi kurang sebesar 5 responden $(26,3 \%)$. Responden yang memiliki sikap kurang dengan perilaku pengendalian hipertensi cukup sebesar 4 responden $(6,1 \%)$, responden yang memiliki sikap cukup dengan perilaku pengendalian hipertensi cukup sebesar 54 responden $(81,8 \%)$, dan responden yang memiliki sikap baik dengan perilaku pengendalian hipertensi cukup sebesar 8 responden $(12,1 \%)$. Responden yang memiliki sikap cukup dengan perilaku pengendalian hipertensi baik sebesar 10 responden $(19,6 \%)$, responden yang memiliki sikap baik dengan perilaku pengendalian hipertensi baik sebesar 41 responden $(80,4 \%)$.

Berdasarkan hasil penelitian dapat dilihat uji korelasi menggunakan uji Somers'd dengan bantuan komputerisasi.didapatkan hasil uji korelasi sikap dengan perilaku pengendalian hipertensi diketahui nilai r sebesar 0,742 dengan p-value $(0.00)$ $<\operatorname{sig}(0,05)$.

Dari hasil tersebut dapat ditarik kesimpulan bahwa terdapat hubungan sikap dengan perilaku pengendalian hipertensi di Desa Jono Kecamatan Tawangharjo Kabupaten Grobogan. Secara nilai korelasi sikap dengan 
perilaku pengendalian hipertensi di Desa Jono Kecamatan Tawangharjo Kabupaten Grobogan dapat dikatakan kuat, artinya sikap memiliki pengaruh yang kuat terhadap perilaku pengendalian hipertensi di Desa Jono Kecamatan Tawangharjo Kabupaten Grobogan.

Hal ini sesuai dengan teori menurut Maulana (2008), yang menyatakan bahwa pendidikan dapat mempengaruhi seseorang termasuk juga perilaku seorang akan pola hidup terutama dalam memotivasi untuk bersikap positif dan berperan serta dalam pembangunan kesehatan. Seseorang akan dapat mengingat kembali tentang sesuatu yang dipelajari sebelumnya dari pengetahuan suatu pendidikan, sehingga dapat memperbaiki tindakan yang akan dilakukan. Seseorang dengan pengetahuan yang tinggi merupakan dasar terwujudnya sikap positif yang kemudian akan dapat diaplikasikan dalam tindakan nyata.

Hasil ini sesuai dengan teori yang menyatakan bahwa sikap secara nyata menunjukkan konotasi adanya kesesuaian reaksi terhadap stimulus tertentu, dalam kehidupan sehari-hari adalah merupakan reaksi yang bersifat emosional terhadap stimulus social (Maulana, 2008). Menurut Newcomb salah seorang ahli psikologi social menyatakan bahwa sikap itu merupakan kesiapan atau kesediaan untuk bertindak dan bukan merupakan kesiapan dan kesediaan untuk bertindak dan bukan merupakan pelaksana motif tertentu. Sikap belum merupakan suatu tindakan atau aktivitas, akan tetapi adalah merupakan presdiposisi tindakan atau perilaku. Sikap itu masih merupakan reaksi tertutup bukan merupakan reaksi terbuka atau tingkah laku yang terbuka.

Suatu sikap belum otomatis terwujud dalam suatu tindakan (overt behavior), untuk terwujudnya sikap menjadi suatu perbuatan nyata yang diperlukan faktor pendukung atau suatu kondisi yang memungkinkan antara lain adalah fasilitas. Hasil dalam penelitian ini sesuai dengan hasil penelitian yang diperoleh dalam penelitian terkait yaitu penelitian yang dilakukan oleh Phitaloka (2010), dengan judul faktor-faktor yang berhubungan dengan pegendalian hipertensi pada lansia di Posyandu Lansia Wilayah Kerja Mojosongo Boyolali 2010, dimana dalam penelitian ini menemukan adanya hubungan antara sikap dengan pengendalian hipertensi pada lansia di 
Posyandu Lansia Wilayah Kerja

Mojosongo Boyolali 2010.

\section{KETERBATASAN PENELITIAN}

Hasil penelitian ini tidak sepenuhnya memenuhi kriteria dan prosedur penelitian yang sempurna. Keterbatasan peneliti dalam penelitian ini adalah peneliti kurang memperhatikan homogenitas karakteristik responden, misalnya status sosial ekonomi responden. Kondisi ini memunkinkan adanya perbedaan perilaku pengendalian hipertensi, sehingga perilaku pengendalian hipertensi disebabkan oleh faktor karakteristik responden tersebut seperti umur, jenis kelamin, pendidikan, dan pekerjaan responden.

\section{KESIMPULAN}

1. Responden dengan pendidikan rendah sebanyak 34 responden (25\%), responden dengan pendidikan menengah 79 responden $(58,1 \%)$, dan responden dengan pendidikan tinggi 23 responden $(16,9 \%)$.

2. Responden yang memiliki sikap kurang sebanyak 18 responden $(13,2 \%)$, responden yang memiliki sikap cukup sebanyak 69 responden $(50,7 \%)$, dan responden yang memiliki sikap baik sebanyak 49 responden $(36,1 \%)$.

3. Responden yang memiliki perilaku kurang sebanyak 19 responden (14\%), responden yang memiliki perilaku cukup sebanyak 66 responden $(48,5 \%)$, dan responden yang memiliki perilaku baik sebanyak 51 responden $(37,5 \%)$.

4. Ada hubungan tingkat pendidikan dengan perilaku pengendalian hipertensi dengan nilai $r \quad(0,633)$ dengan p-value $(0,00)<\operatorname{sig}(0,05)$. Kekuatan korelasi antara variabel tingkat pendidikan dan perilaku pengendalian hipertensi sebesar 0,633

5. Ada hubungan sikap dengan perilaku pengendalian hipertensi dengan nilai $r$ $(0,742)$ dengan $p$-value $(0,00)<\operatorname{sig}$ $(0,05)$. Kekuatan korelasi antara variabel sikap dan perilaku pengendalian hipertensi sebesar 0,742 .

\section{DAFTAR PUSTAKA}

Baradero, Mary. 2008. Klien Gangguan Kardiovaskuler: Seri Asuhan Keperawatan. Jakarta: EGC

Bensley, Robert $\mathrm{J}$ and Jody Brookins Fisher. 2009. Metode Pendidikan Kesehatan Masyarakat(Terjemahan). Jakarta: EGC

Dalimartha, Setiawan. 2008. Care yourself hipertensi. Jakarta: Penebar Plus

Dahlan, Sopiyudin. 2011. Statistik untuk Kedokteran dan Kesehatan. Depok: Bina Mitra Press.

Departemen Kesehatan RI. 2012. Penyakit Tidak Menular. Jakarta: Buletin Jendela Data dan Informasi Kesehatan Semester II 
Demaio, Alessandro R., Dugee Otgontuya, Maximilian De Courten, IBC Bygbjerg, Palam Enkhtuya, W. Meyrowitsch, \& Janchiv Oyunbileg. 2013. Hypertension and Hypertension-Related Disease in Mongolia; Findings of a National Knowledge, Attitudes and Practices Study. BMC Public Health 13, 194

Dewi, Dwina Pramita. 2011. Hubungan Pengetahuan dan Sikap Tentang Hipertensi dengan Pengendalian Hipertensi pada Lansia di Posyandu Lansia RW 09 Kelurahan Jati Padang Pasar minggu Tahun 2011 (Skripsi). Jakarta: Universitas Pembangunan Nasional "Vereran"

Dinas Kesehatan Kabupaten Grobogan. 2013. Profil Kesehatan Kabupaten Grobogan. Grobogan: Dinkes Kab. Grobogan

Dinas Kesehatan Provinsi Jawa Tengah. 2011. Profil Kesehatan Provinsi Jawa Tengah Tahun 2011. Jawa Tengah: Dinkesprov Jateng

Hidayat, Alimul Azis. 2009. Metode Penelitian Kebidanan dan Tehnik Analisis Data. Jakarta: Salemba Medika

Kurniati, Apriana, Ari Udiyono, dan Linda Dian Saraswati. 2012. Gambaran Kebiasaan Merokok Dengan Profil Tekanan Darah Pada Mahasiswa Perokok Laki-Laki Usia 18 - 22 Tahun (Studi Kasus di Fakultas Tehnik Jurusan Geologi Universitas Diponegoro Semarang). Jurnal Kesehatan Masyarakat Volume 1 Nomor 2 halaman 251 - 261

Kuswardhani, Tuty RA. 2008. Penatalaksanaan Hipertensi pada Lanjut Usia. Divisi Geriatri Bagian Penyakit Dalam FK. Unud, RSUP Sanglah Denpasar. Posted on Jan 2, 2008
Lubis, Harun Rasyid. 2008 . Sejarah Hipertensi. Divisi Ginjal dan Hipertensi Departemen Ilmu Penyakit Dalam FK USU. Posted on November 10, 2008

Mahardani, Ni Made Ayu Fera. 2010. Pengaruh Senam Jantung Sehat Terhadap Tekanan Darah Pada Penderita Hipertensi Di Klub Jantung Sehat Klinik Kardiovaskular RS Hospital Cinere (Skripsi). Jakarta: Universitas Pembangunan Nasional "Veteran" Jakarta.

Maulana, DJ Heri. (2009). Promosi Kesehatan. Jakarta: EGC

Mariyam, dkk. 2008. Mengenal Usia Lanjut dan Perawatannya. Jakarta: Salemba Medika.

National Heart Lung and Blood Institute. 2008. High Blood Pressure. Retrieved January 3, 2014, from http://www.nhlbi.nih.gov/health/dci/ Diseases/Hbp/HBP_WhatIs.html

Notoatmodjo, Soekidjo. 2005. Metodologi Penelitian Kesehatan. Jakarta: PT Rineka Cipta

Nugroho,W. 2009. Keperawatan Gerontik, Edisi-2. Jakarta: EGC

Puskesmas Tawangharjo. 2013. Prevalensi Penderita Hipertensi. Tawangharjo: Puskesmas Tawangharjo

Rahajeng, Ekowati \& Sulistyowati Tuminah. 2010. Prevalensi Hipertensi dan Determinannya di Indonesia. Jakarta: Pusat Penelitian Biomedis dan Farmasi Badan Penelitian Kesehatan Departemen Kesehatan RI

Riwidikdo, Handoko. 2009. Statistik Kesehatan: Belajar Mudah Teknik Analisis Data dalam Penelitian Kesehatan. Yogyakarta: Mitra Cendikia. 
Sabouhi, Fakhri, Sima Babaee, Homayoon Naji, \& Akbar Hassan Zadeh. 2011. Knowledge, Awarness, Attitudes, and Practice about Hypertension in Hypertensive Patients Reffering to Public Health Care Centers In Khoor \& Biabanak. Iran J Nurs Midwifery Res 16 (1): 34 - 40

Sampurna. 2008. Konsep Keluarga Lansia. Retrieved January 14, 2014, from http://sampoernae.blogspot.com/200 8/10/konsep-keluarga-lansia.html

Saryono. 2009. Metodologi Penelitian Kesehatan: Penuntun Praktis Bagi Pemula. Yogjakarta: Mitra Cendekia Press.

Sustrani, Lanny, Syamsir Alam, \& Iwan Hadibroto. 2006. Hipertensi. Jakarta: PT Gramedia Pustaka Utama.
Sutomo, Budi. 2008. Menu Sehat Penakluk Hipertensi. Jakarta: De Media Pustaka.

Syaikh, Mumtaz Ali, Dure Yakta, Sadia, \& Raj Kumar. 2012. Hypertension Knowledge, Attitude and Practice in Adult Hypertensive Patient at LUMHS. JLUMHS vol 11 no 02

Wasis. 2008. Pedoman Riset Praktis: untuk Profesi Perawat. Jakarta: EGC.

Williams, Wendell H., Robert E. Safford, Michael G. Heckman, Julia E. Crook, Charles D. Burger. 2010. Pulmonary Arterial Hypertension and Obesity. The open Obesity Journal., 2, 132-136

World Heath Day. 2013. High Blood Pressure Global and Regional Overview. World Health Organization 